\title{
The Determinants of the Choices of Payment Methods for Goods and Services Transaction in Vietnam
}

\author{
Cuong Nguyen ${ }^{1}$, Dung Dinh ${ }^{2} \&$ Thanh Doan ${ }^{2}$ \\ ${ }^{1}$ Faculty of Business Administration, Industrial University of Ho Chi Minh City, Vietnam \\ ${ }^{2}$ Business Department, FPT University, Vietnam \\ Correspondence: Cuong Nguyen, Faculty of Business Administration, Industrial University of Ho Chi Minh City. \\ ZIP/Post code: 70000, Vietnam.
}

Received: August 12, 2018; Accepted: September 26, 2018; Published: December 17, 2018

\begin{abstract}
The main objective of this study is to determine the main factors that have influences on customers' decision to choose their payment methods. The research model applied in this study is Theory of Reasoned Action. The paper investigates 400 respondents in Vietnam to find out the determinants of their choice of payment methods. The implications from this study is expected to help financial service providers to improve the rate of using modern payment methods and improve customer satisfaction on the quality of payment services.
\end{abstract}

Keywords: payment methods, Theory of Reasoned Action, payment for products and services, Vietnam

\section{Introduction}

Since many years ago, people has used money in coins and cash form to perform worldwide business transaction. However currently in modern days, the appearance of credit card payment practice. becomes much more convenient. Hence, e-wallet, QR code, online transactions and smart cards are used as a replacement of cash. Many people currently don't want to use cash as priority payment practice. $90 \%$ total transactions in developed countries via World Bank are non-cash transactions, according to its survey. In 2016, here are only $7.7 \%$ and $10 \%$ of cash transactions in America and Europe, respectively, according to Lupu et al. (2016). Although the bank accounts are increasingly opened in recent years, the banks do not provide much banking service in isolated places which are needed focusing and covering with more information to be recognized. The Ministry of Industry and Trade did a survey in 2015 and concluded that bank transfer and payment by cash are popular in Vietnam. Vietnam is trying to achieve $90 \%$ of non-cash economy by 2020 by decreasing transactions made by cash and then replacing other payment practices using electronic devices, according to Briefing and Das, 2016 researched by Dezan Shira \& Associates. However, the government is facing difficult job for its target to be done with the fact that there are still $90 \%$ of cash transactions and $30 \%$ of Vietnamese people owning bank account currently. Vietnam is still included in the list of countries which has nearly $90 \%$ of transactions made by cash. There are many reasons for that, however the lack of ATMs and non-cash payment systems are principle reasons. Moreover, electronic practices are complex and not easy to use thus leads to the losing of customer's faith. There were 16.8 million bank accounts in 2010 and the number for 2011 is 67.4 million (Citiesalliance.org, 2011). The aim of this study is to determine elements which affect customer's choice of payment practices to provide information for financial organizations in order to improve their service to fulfill customer's satisfaction. There are some assumptions in gathering information and data for research which aim to enhance the achievement of case study organization (Kumar, 2008). There was more than 250 people being asked with question through $\mathrm{X}$ questions, 3 to 5 minutes was given to answer the questions. Exploratory Factor Analysis and SPSS 20 together performed the process of data.

\section{Literature Review}

Understanding about how people's rational in making decision on what service or product they want to buy or to use is all about consumer behavior study (Kardes, et al., 2008, 8-9). The Theory of Reasoned Action studied by Fishbein and Ajzen (1974) defines the relation between buyer's behavior and their attitudes under human action. The valuable conclusion from the theory is that consumers will behave with their intention to make or receive a pleased result. Hence, the people working in marketing department could use the theory to improve their strategy better for business. Customers will focus on the expected result to decide the purchase. In marketing, understanding about customer's satisfaction is an important term which is not easy to understand and apply. There has been a lot of explanations to define customer satisfaction for years. Customer satisfaction is treated as how much customer's 
expectation to be met from using a product or service. Customer satisfaction is also defined through customer's fulfilment response according to Zeithaml (1990). It is not clear whether product or service feature, or the product or service itself providing a pleased fulfilment. In addition, customer prefer to receive and pay bills in the way which is suitable with their lives' speed and demand. There are main features dependent to customer's bill payment attitude which are satisfaction, security and speed. There was about 3,001 American were questioned about what their expectation for a bill payment system and the answers was were all about an accessible and acceptable payment experience, according to Fiserv.com, 2014. Being asked about the most secure way for the bill's payment and receipt, there was $33 \%$ of responders saying that they wish to pay bill directly and $32 \%$ of them preferring to pay bill via bank. The other $25 \%$ said they want to mail, $8 \%$ of them like email and the remaining $2 \%$ choose nonbanking number. Otherwise, $57 \%$ of American who did the survey chose debit, credit and prepaid bank cards. The intention of this survey is to show how dependent the payment practices and customer satisfaction is. 10 responders said that their pleasure fulfilment will be increased if there are more options to pay bill and $66 \%$ of them preferred non-paper bills (Fiserv.com, 2014).

Over years, there are many options for consumer to perform their payment. They used to use physical coins or cash for payment and now they can choose among checks, credit cards, debit cards and many other practices. There are many businesses offering their own cards for customer using at their stores. Customer's behavior has been changing with the development in number of payment practices and could become unpredictable. Schuh and Stavins' research in 2011 showed that consumers have so many options for their payments among paper instruments (cash, money orders, check, traveler's checks), payment cards (debit cards, credit cards, prepaid cards), online payments (online banking bill payment, bank account number payments). Consumer's behavior in choosing payment practices will depend on their income, age, credit history, asset holdings, debt, rationality. Younger, less educated, poorer and lower income use cash and debit card, especially single persons while older people with better educated, higher income and the wealthier mostly use credit card. Year by year, customer's behavior in payment practices other than traditional one has led to the launching of new payment ways.

\subsection{Theory of Reasoned Action}

Built in 1974 by Aizen and Fishbein, Theory of Reasoned Action (TRA) was the result of learning about behavior from expectancy value models. Accordingly, a behavior of a person is defined by his/her intention in turn affects his/her attitude toward the behavior and subjective norm. TRA model also anticipates the intention taken behavior into action by consumer's attitude towards that behavior. "Attitude" was defined as the personal evaluation of an object and the connections between an object and some attribute was "belief" and "behavior" as result or intention, by Fishbein and Ajzen (1974).

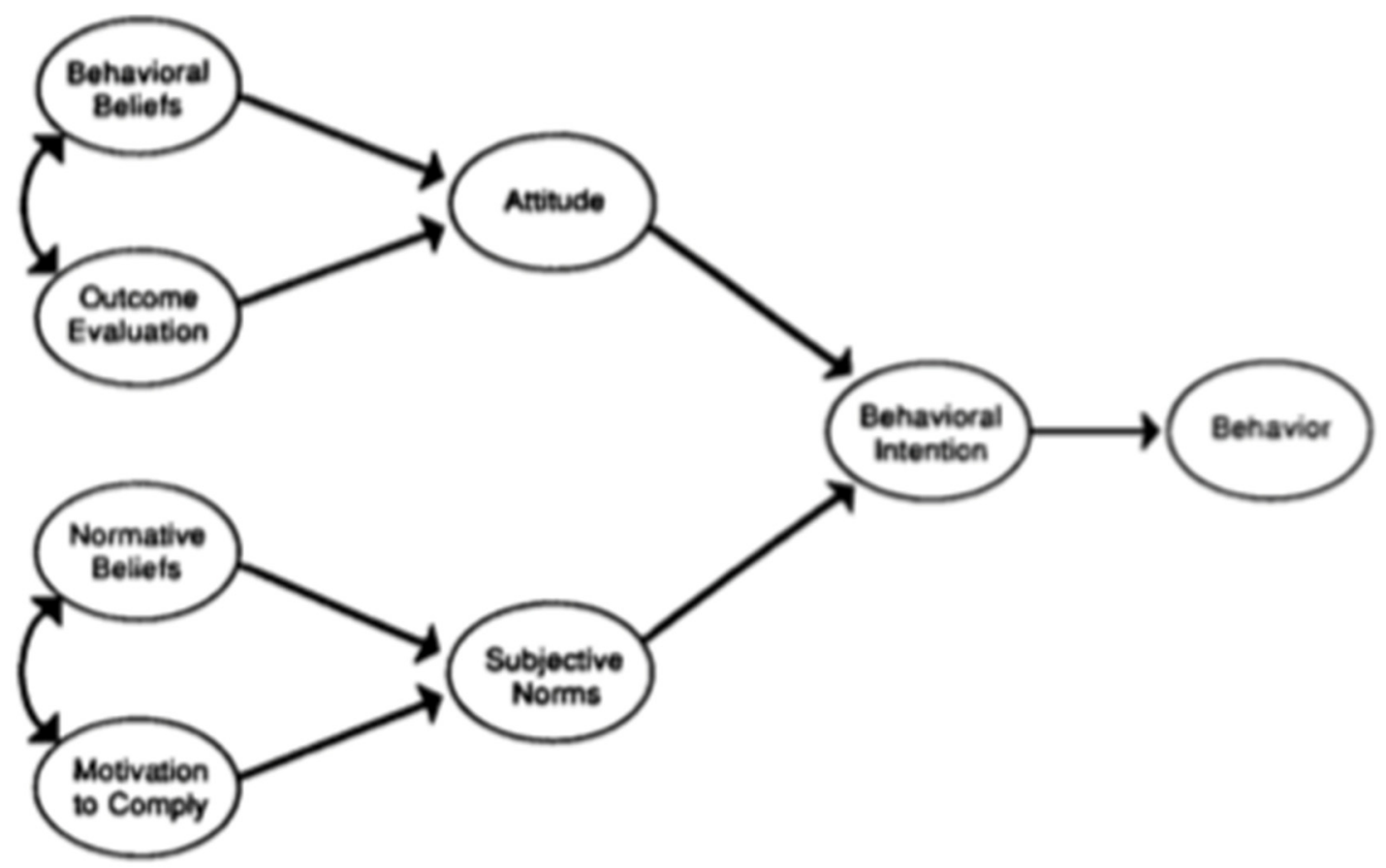

Figure 1. Theory of Reasoned Action (Fishbein and Ajzen, 1974) 
To learn about customer's behavior, TRA model is a proper tool to use because it anticipates attitudes, values and beliefs affecting people's choices, according to Utami (2016). Also, customer's expectation in payment is affected by intuition of characteristics, acceptances, together with social rules like feelings, characters and control. Attitude and subjective norms affect the behavior. Where the behavioral beliefs and outcome evaluation of the individual will form attitude toward behavioral intention. Normative beliefs as well as motivation to comply influences subjective norms that form up a behavioral intention. Firstly, it is evident to show that consumers' payment attitudes depend on perceived attributes, especially perceived safety and acceptance. Secondly, it shows that attitude drives payment intentions, together with social norms, roles, emotions, and perceived control. Emotions are particularly important in this respect. Lastly, it revealed that although payment intentions are the key driver of payment behavior, payment habits also play an important role in explaining how consumers pay. The role of actual control over the payment situation, like having enough money in the wallet when you want to pay cash or not experiencing technical disturbances when you want to pay electronically, is limited (Cruijisen 2016).

\section{Research Design}

\subsection{Independent Variables}

In Demographic below includes 06 independent variables (gender, age, career, income, working field and academic level) being coded. For gender, 1 is coded for male and 2 for female. For age, 1 to 4 are coded for "from 18 - 25 years old", "from 26 - 30 years old", "from 31 - 45 years old" and "over 45 years old", respectively. About academic level, 1 is coded for "high school", 2 for "college", 4 for "university" and 4 for "post-university". Regarding to income (VND), 1-4 are coded respectively for "Under 10 million", "from 10 - 15 million", "from 15-20 million" and "over 20 million". With working field, 1 is coded for "industrial", 2 for "agriculture", 3 for "service" and 4 for "trading". Then, with career, 1 is coded for "governmental company", 2 as "private company", 3 for "foreign company" and 4 for "self-employed".

There are 4 independent variables in the list of questions with 4 dimensions and 24 questions. In which, 10 questions for Behavioral beliefs, 7 questions for Outcome evaluations, 4 questions for Normative reliefs, 5 questions for Motivation to comply. There are advantageous and disadvantageous attitude toward behavior in Behavioral beliefs part. In Outcome evaluations part, the questions are about how and what consumers' personal rate for their behavior outcome. Normative beliefs questions are how external factors influence internal factors indirectly. Like, how their friends think about a behavior which could influence their feelings about behaviors themselves. Motivation to comply is how or what external factors influence internal factors directly. Like, if certain places only offer their customers to pay by cash, will customer's behavior in payment be affected directly? Answers will be done in 7 Likert - Sale from totally disagree to totally agree (coded from 1 - 7).

\subsection{Dependent Variables}

The dependent variable is behavioral intention with the consumption that behavioral intention is depended on Attitude toward behavior and subjective rules. Based on TRA, attitude rules and subjective rules define the behavioral intention which was proofed as below. Behavioral intention is person's perceived likelihood or "subjective probability that he or she will engage in a given behavior" (Committee on Communication for Behavior Change in the 21st Century, 2002, p. 31). Aattitude is the key to understand the human behavior (Thomas and Znaniecki, 1918). Subjective norms refer to the belief that an important person or group of people will approve and support a particular behavior. According to Venkatesh and Davis (2000), Subjective norm represent the individual's behavior that they perform, even if they are not inclined toward the behavior. According to the theory of reasoned action (TRA), subjective norms basing on normative beliefs and motivation to comply. Eckhardt et al. (2009) explain subjective norms can be comprehended as one's awareness of social burden from their important people such as their parents, friends and the others). Hox et al. (1995) conduct a survey based on the TRA with 462 cases and the result showed that the attitude norms and subjective norms do dependent to the behavioral intention. Behavioral intention is dependent variable and depends on attitude rules. The variable is included in Question 32 to Question 34 with people's intention of not using cash to perform payment.

\subsection{Sample Size}

Samples in the research are got from both online and offline survey and 100 is the minimum sample for reasonable result. 


\begin{tabular}{|r|c|c|c|c|c|c|} 
& \multicolumn{7}{|c|}{ Size of population } \\
Margin of error & $>5000$ & 5000 & 2500 & 1000 & 500 & 200 \\
\hline $\pm 10 \%$ & 96 & 94 & 93 & 88 & 81 & 65 \\
\hline $\mathbf{7 . 5 \%}$ & 171 & 165 & 160 & 146 & 127 & 92 \\
\hline $\mathbf{5} \%$ & 384 & 357 & 333 & 278 & 217 & 132 \\
\hline $\mathbf{3} \%$ & 1067 & 880 & 748 & 516 & 341 & 169 \\
\hline
\end{tabular}

From the table above, smallest sample are about 100 and the biggest one is about 1000 . With population of 10,000 , $10 \%$ of which is 1,000 people giving quite trust answer. If the sample was more than 1,000 , the result would not be affected anyway but increase cost and time to do the survey. Comrey and Lee (1992) said that "The adequacy of sample size might be evaluated very roughly on the following scale: 50 - very poor, 100 - poor, 200 - fair, 300 - good, 500 - very good, 1000 and more - excellent". Moreover, Hair et al. (1998) also added that, sample size is at least 5 times as many observations as variables. Our survey's total sample to be tested is 400 , while half of which was done online, the remaining was done with offline responders.

\subsection{Sample Collection}

Most of the surveys were done in café and banks where people do not usually pay by cash. These are suitable place for the survey to be done with reliable result although not all people were willing to give the responses. With online survey, google form is used to collect answer thus the time is not limited during the survey duration. The survey also assures for the privacy of information dependent to the responders that only people carrying the research are able to assess to the data.

\subsection{Data Analysis}

Analysing the data includes investigating, clearing and modeling the input to extract only useful information for the result. Normally the data was classified into descriptive statistics, exploratory data analysis and confirmatory data information.

This research collected answers and checked for wrong input. Descriptive statistics and a Reliability rest were performed (Testing Cronbach's Alpha) before Exploratory Factor Analysis (Testing Factor Loading) and Checking Collinearity (Testing Pearson Correlation) so that the result could be reliable. Finally, Regression Analysis will be done for the outcome of research.

\section{Results}

Once samples were collected, the total number of responses was 373 including online and offline which were analyzed with SPSS 20. Gender, age, education level, nature of company, working field and income are included in descriptive analysis. Unreasonable input would be removed during Reliability test then Exploratory factor analysis was carried thereafter. Multi-collinearity test then was performed in order to test the correlation between independent variables. Also, multiple regressions were done to test the equation and check the affection from elements that influenced their intentions using non-cash payment practices. Finally, One-Way ANOVA test was run to compare the means and differentiate demographic groups.

\subsection{Gender}

This part describes results from above surveys which there was 208 males and 165 females as below:

\section{Gender}

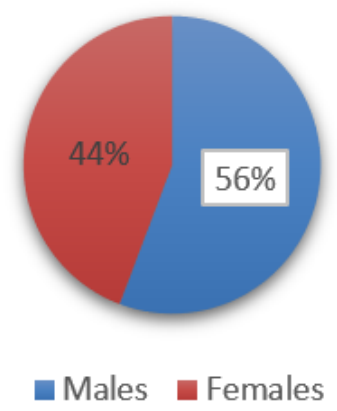

Figure 2. Male/ Female Ratio 
Table 1. Description of Gender

\begin{tabular}{llllll}
\hline Gender & \multicolumn{5}{l}{} \\
\hline \multirow{4}{*}{ Valid } & 1 & Frequency & Percent & Valid Percent & Cumulative Percent \\
& 2 & 208 & 55,8 & 55,8 & 55,8 \\
& Total & 373 & 44,2 & 44,2 & 100,0 \\
& & 165 & 100,0 & 100,0 & \\
\hline
\end{tabular}

There are almost no differences dependent to genders thus no influence on the results of how people behave with non-cash payment practices. Elements such as age and gender were assumed to influence customers react and behavior to payment practices.

\subsection{Age}

One of the most important factors to determine about how different customer's behavior is in different duration of life. With age, there was 272 responders aging from 18-25, 47 of whom aging from 26-30, 36 of whom aging from $31-45$ and 18 aging above 45 , as followings:

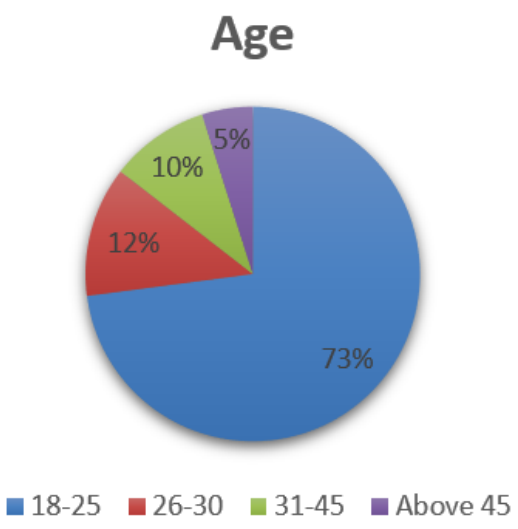

Figure 3. Age ranges

Table 2. Description of Age ranges

\begin{tabular}{|c|c|c|c|c|c|}
\hline \multicolumn{6}{|c|}{ Age range } \\
\hline & & Frequency & Percent & Valid Percent & Cumulative Percent \\
\hline \multirow{5}{*}{ Valid } & 1 & 272 & 72,9 & 72,9 & 72,9 \\
\hline & 2 & 48 & 12,9 & 12,9 & 85,8 \\
\hline & 3 & 37 & 9,9 & 9,9 & 95,7 \\
\hline & 4 & 16 & 4,3 & 4,3 & 100,0 \\
\hline & Total & 373 & 100,0 & 100,0 & \\
\hline
\end{tabular}

From the table, the result was almost taken from people in age of 18-25 whom were asked on their behavior on using non-cash payment practices.

\subsection{Educational Level}

For educational level factor, there was 37 of responders from high school, 45 from colleges, 255 from universities and 35 from post-universities. Additionally, $68 \%$ of responders having university degree, and $12 \%$ had college degree, details as below: 


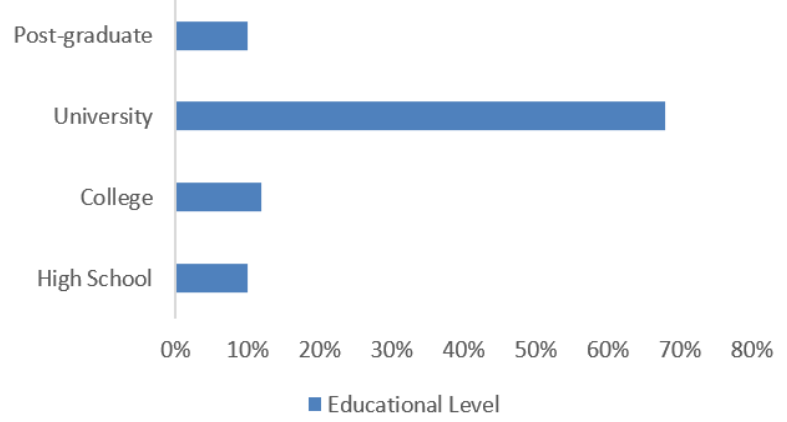

Figure 4. Education level

Table 3. Description of Education level

\begin{tabular}{llllll}
\hline Educational level & & & & \\
\hline & & Frequency & Percent & Valid Percent & Cumulative Percent \\
\hline \multirow{4}{*}{ Valid } & 1 & 37 & 9,9 & 9,9 & 9,9 \\
& 2 & 46 & 12,3 & 12,3 & 22,3 \\
& 3 & 256 & 68,6 & 68,6 & 90,9 \\
& 4 & 34 & 9,1 & 9,1 & 100,0 \\
& Total & 373 & 100,0 & 100,0 & \\
\hline
\end{tabular}

Almost people who took the questionnaires are in well-educated, so the result was reflected better including information about internet banking and e-wallet.

\subsection{Exploratory Factor Analysis}

Once Reliability test is done, Exploratory Factor Analysis (EFA) test will be carried thereafter. Ratio of .5 participants per measured variable and sample should not less than 100 according to Gorsuch (1983). Also, ratios of .1 to 1. and total cases should be over than 300 to be tested based on Field (2005) and communalities after extraction should be probably be above .5 according to Nunally (1978) and Everitt (1975). Kaiser-Meyer-Olkin (KMO) Test gives us the values from 0 to 1 . The world-over accepted index is over .6 and the Barlett's Test of Sphericity must be less than .05 . The results of KMO and Barlett's Test are as followings:

Table 4. The first KMO and Barlett's Test

\begin{tabular}{lll}
\hline KMO and Bartlett's Test & \\
\hline Kaiser-Meyer-Olkin Measure of Sampling Adequacy. & Approx. Chi-Square & .900 \\
& df & 4080.679 \\
Bartlett's Test of Sphericity & Sig. & 325 \\
& & .000 \\
\hline
\end{tabular}

Outcome from The KMO was .900 which explained that there was suitable connection of the data. Result from Barlett'Test was 0.000 which explained that Exploratory Factor Analysis could be sued in 21 questions. When EFA test was performed as the first time, there were 21 variables of TRA model giving value higher than .5. Additionally, the values were linked with others. Data was removed for the question number values less than .5 . After omitting question 13, 14, 15, 18, 23, 16 variables left will be applied with EFA. Also, 16 variables will be tested with KMP and the Barlett's Test of Sphericity. Results of KMO and Barlett's test are below.

Table 5. The second KMO and Barlett's Test

\begin{tabular}{lll}
\hline KMO and Bartlett's Test & & \\
\hline Kaiser-Meyer-Olkin Measure of Sampling Adequacy. & & .907 \\
Bartlett's Test of Sphericity & Approx. Chi-Square & 3486.530 \\
& df & 210 \\
& Sig. & .000 \\
\hline
\end{tabular}


The outcome of 0.907 explained the good relation of data as shown above. Result of the Barkett's test of Sphericity is 0.000 which explained the significant connection. Thus, it is suitable to apply the data in EFA within 16 questions. In the next test of EFA, the value is higher than .5 for all the variables which explained that these values were well connected with others. Component 1 was included in question 7, 8, 9, 10,11, 12 and 16 whose factor name is Belief Behavior according to Rotated Component Matrix and question 17, 19, 20, 21, 22 includes component 2 which belong to Outcome evaluation as named of the factor. Normative Belief is factor in Question 24, 25, 26, 27. Last component in question 28, 29, 30 has factor as Motivation Comply.

\subsection{Regression Analysis}

To anticipate and define the connections of independent variables and dependent variables, the research used multiple linear regression technique. There are 4 elements of independent variables included in model in this study and multiple linear regression practice shows the rate of influence on dependent variables, called as behavior intention (B.I). SPSS 20 software is used to present level of influence of 4 factors which are N.B, O.E, B.B and M.C with independent variable B.I.

Table 6. Model Summary

\begin{tabular}{lllll}
\hline \multicolumn{2}{l}{ Model Summary } & & & \\
\hline Model & $\mathrm{R}$ & R Square & Adjusted R Square & Std. Error of the Estimate \\
1 & $.752^{\mathrm{a}}$ & .566 & .561 & 2.278 \\
\hline
\end{tabular}

a. Predictors: (Constant), N.B, M.C, O.E, B.B

b. Dependent Variable: B.I

From above model, the outcome of Adjusted R Square is .561 which means that rate of influence from independent variables on dependent variable. Also, independent variables influenced dependent variable. The remaining are other elements not included in model or error outcome.

Table 7. ANOVA Analysis

\begin{tabular}{lllllll}
\hline ANOVA $^{\mathrm{a}}$ & & & & & \\
\hline Model & & Sum of Squares & df & Mean Square & F & Sig. \\
& Regression & 2472.400 & 4 & 618.100 & 119.162 & $.000^{\mathrm{b}}$ \\
1 & Residual & 1898.457 & 366 & 5.187 & & \\
& Total & 4370.857 & 370 & & & \\
\hline
\end{tabular}

a. Dependent Variable: B.I

b. Predictors: (Constant), N.B, M.C, O.E, B.B.

ANOVA test shows significant of 0.000 which is less than 0.05 thus this model fits well. Sig. is smaller $5 \%(0.000)$ means that the connection of factors in the model showed the variance of dependent factor.

Based on table Coefficients below, the significant of independent variable N.B is .886 which is $>0.05$ showing that N.B independent variable is eliminated from the model in this research because it is insignificant. The remaining have significant of $0.000<0.05$ so it has the meaning of explanation for dependent variable B.I

Table 8. Coefficeints

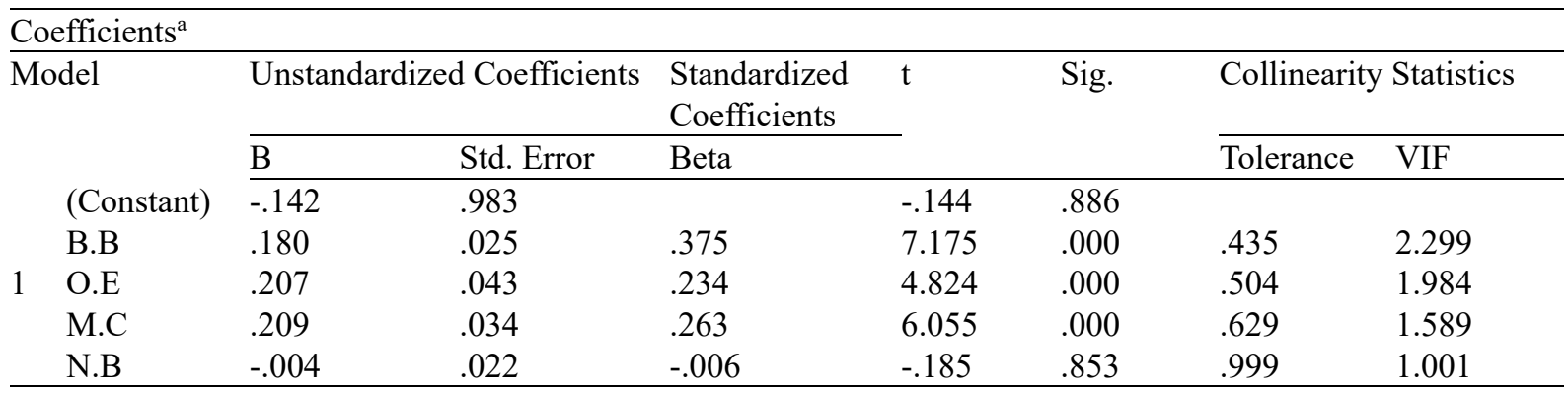


The equation of linear regression is: $\mathrm{Y}=\mathrm{B}_{1} \mathrm{X}_{1}+\mathrm{B}_{2} \mathrm{X}_{2}+\mathrm{B}_{3} \mathrm{X}_{3}+\mathrm{B}_{\mathrm{n}} \mathrm{X}_{\mathrm{n}}$. In which, for our study the multiple linear regression based on the coefficients is: B.I $=\mathbf{0 . 3 7 5} * \mathbf{B} . \mathbf{B}+\mathbf{0 . 2 3 4} * \mathbf{O . E}+\mathbf{0 . 2 6 3} * \mathbf{M}$.C. The increase of factors influences behavior intention of using non-cash payment practices, according to the positive coefficient. 0.375 is the largest coefficient of B.I which means the largest influence in the model and the next one of 0.263 is M.C, the last one is O.E with coefficient of 0.234. The high Beta value shows the higher influence of independent variables on dependent variables related to the customer's behavior intention in using cash or non-cash payment practices.

\section{Conclusion}

According to regression analysis and 4 factors affecting behavior intention of using non-cash payment practices, the remaining part of this study suggest increasing behavior intention of using non-cash payment practices. The equation mentioned above as: B.I $=0.375 * \mathrm{~B} . \mathrm{B}+0.234 * \mathrm{O} . \mathrm{E}+0.263 * \mathrm{M} . \mathrm{C}$ which is possible for the highest outcome is behavior belief and next ones are motivation to comply and outcome evaluation, respectively. Hence, to increase customer's behavior belief is to lead to behavior of using non-cash payment practices. Personal objective about the information and level of education of customer are related to behavior belief to decide payment practices. The belief in service provided is very important thus educating customers and provide information to make them understand about practices of payment should be improved and next, the motivation to comply affects subjective norms and affected by surrounding environment. The services accepting different payment practices will adjust the motivation to comply. Another suggestion is the evaluation of result which is together with behavior belief. Personal attitude includes both of that when using the service. Outcome evaluation is about customer's expectation to gain from an issue, but behavior belief is personal belief about the issue. Thus, spreading good information to highlight the result of using non-cash payment practices will influence outcome evaluation and affect behavior intention of customers. 0.234 unit of behavior intention will be from 1 unit of outcome evaluation. In summary, there should be more research to be carried to determine more elements which could affect behavior intention in regards of using non-cash payment practices in Vietnam.

\section{Acknowledgments}

Authors have no grants or other financial support for this study. Authors declare there is no conflict of interest in this study.

\section{References}

Anderson, E. W., \& Fornell, C. (2000). Foundations of the American customer satisfaction index. Total Quality Management, 11(7), 869-882. https://doi.org/10.1080/09544120050135425

Baron, S., \& Harris, K. (2003). Services Marketing. 2nd ed. Basingstoke: Palgrave.

Bendle, N., Farris, P., Pfeifer, P., \& Reibstein, D. (2010). Metrics that Matter - to Marketing Managers. Marketing ZFP, 32(JRM 1), 18-23. https://doi.org/10.15358/0344-1369-2010-JRM-1-18

BRAC Business School. (2006). Customer Satisfaction of Jamuna Bank Limited. Retrieved 28 February, 2018, from http://dspace.bracu.ac.bd/bitstream/handle/10361/3024/09304088.pdf? sequence=1

Briefing, V., \& Das, K. (2018). Vietnam's Payment Preferences: Four Trends to Watch - Vietnam Briefing News. [online] Vietnam Briefing News. Retrieved 4 Octtober, 2016, from http://www.vietnambriefing.com/news/vietnams-payment-preferences-4-trends-watch.html/

Cardozo, R. N. (1965). An Experimental Study of Customer Effort, Expectation and Satisfaction. Journal of Marketing Research, 2, 244-249. https://doi.org/10.2307/3150182

Ching, A. T., \& Hayashi, F. (2010). Payment card rewards programs and consumer payment choice. Journal of Banking \& Finance, 34(8), 1773-1787. https://doi.org/10.1016/j.jbankfin.2010.03.015

Citiesalliance.org (2011). Retrieved 4 Octtober, 2016, from http://www.citiesalliance.org/sites/citiesalliance.org/files/CAFiles/Projects/Final_669160ESW0P1130Revie w000Full0report.pdf

Comrey, A. L., \& Lee, H. B. (1992). Interpretation and application of factor analytic results. Comrey AL, Lee HB. A First Course in Factor Analysis, 2, 1992.

Cornell, C., Johnson, M. D., Anderson, E. W., Cha, J., \& Everitt Bryant, B. (1996). Growing the trust relationship [Electronic version]. Journal of Marketing, 60(4), 7-18. Retrieved [insert date], from Cornell University, School of Hospitality

Cruijsen, C., de Haan, J., \& Jansen, D. J. (2016). Trust and financial crisis experiences. Social Indicators Research, 127(2), 577-600. https://doi.org/10.1007/s11205-015-0984-8 
Drummond, G., \& Ensor, J. (2005). Introduction to Marketing Concepts. 1st ed. Oxford: Elsevier ButterworthHeinemann.

Farris, P. W., Bendle, N., Pfeifer, P., \& Reibstein, D. (2010). Marketing metrics: The definitive guide to measuring marketing performance. Pearson Education.

Fiserv.com (2014). Retrieved 4 Octtober 2016, from https://www.fiserv.com/resources/Boosting-SatisfactionLoyalty-Billing-Payments-Research-Paper-November-2014.pdf

Fishbein, M., \& Ajzen, I. (1974). Attitudes towards objects as predictors of single and multiple behavioral criteria. Psychological Review, 81(1), 59. https://doi.org/10.1037/h0035872

Gilmore, A. (2003). Services Marketing and Management. 1st ed. London: SAGE Publications Ltd .

Hair, J. F., Anderson, R. E., Tatham, R. L., \& Black, W. C. (1998). Multivariate data analysis. 1998. Upper Saddle River.

Hawkins, D., Mothersbaugh, D., \& Best, R. (2008). Consumer behavior. Princeton, N.J.: Recording for the Blind \& Dyslexic.

Hox, J., de Leeuw, E., \& Vorst, H. (1995). Survey participation as reasoned action; a behavioral paradigm for survey nonresponse? Bulletin of Sociological Methodology/Bulletin de Méthodologie Sociologique, 48(1), 52-67. https://doi.org/10.1177/075910639504800109

Kotler, P. (2003). Marketing Management, 11th European edition, Prentice Hall.

Lupu, S., Mual, M., \& van Stipout, M. (2016). Ecommerce Payment Methods Report 2016. Nguyen, T. T., 2015. A research on customer behavior when using payment bank cards at Vietnam Technological and Commercial Joint Stock Bank-Techcombank Nguyen Hue, Danang, Vietnam.

Oliver, R. L., \& DeSarbo, W. S. (1988). Response determinants in satisfaction judgments. Journal of Consumer Research, 14, 495-507. https://doi.org/10.1086/209131

Scheib, S., Satkulvanich, D. P., \& Altan, D. T. (2008). Examining edge cracking in hole flanging of AHSS. Part II: Modeling of blanking, Stamping Journal.

Schuh, S., \& Stavins, J. (2018). How Consumers Pay: Adoption and Use of Payments.

Schuh, S., \& Stavins, J. (2018). How Do Speed and Security Influence Consumers' Payment Behavior?

Schuh, S., \& Stavins, J. (2018). The 2011 and 2012 Surveys of Consumer Payment Choice.

Spratlin, J. L., Serkova, N. J., \& Eckhardt, S. G. (2009). Clinical applications of metabolomics in oncology: A review. Clinical Cancer Research, 15(2), 431-440. https://doi.org/10.1158/1078-0432.CCR-08-1059

Thomas, W. I., \& Znaniecki, F. (1918). The Polish peasant in Europe and America: Monograph of an immigrant group (Vol. 2). University of Chicago Press.

Van Jaarsveld, C., \& Van Heerden (2007). The relationship between selected marketing mix elements and overall customer satisfaction in South African banks. [online] Repository.up.ac.za. Retrieved 28 February, 2018, from https://repository.up.ac.za/handle/2263/8671

Venkatesh, V., \& Davis, F. D. (2000). A theoretical extension of the technology acceptance model: Four $\begin{array}{llll}\text { longitudinal field } & \text { studies. Management } & \text { Science, 46(2), }\end{array}$ https://doi.org/10.1287/mnsc.46.2.186.11926

$\mathrm{Wu}, \mathrm{K}$. (2011). The role of consumption emotion in the hotel and resort spa experience. Hong Kong: School of Hotel and Tourism Management, The Hong Kong Polytechnic University.

Zeithaml, V. A., Parasuraman, A., Berry, L. L., \& Berry, L. L. (1990). Delivering quality service: Balancing customer perceptions and expectations. Simon and Schuster.

\section{Copyrights}

Copyright for this article is retained by the author(s), with first publication rights granted to the journal.

This is an open-access article distributed under the terms and conditions of the Creative Commons Attribution license (http://creativecommons.org/licenses/by/4.0/). 